Jusmal lemiah
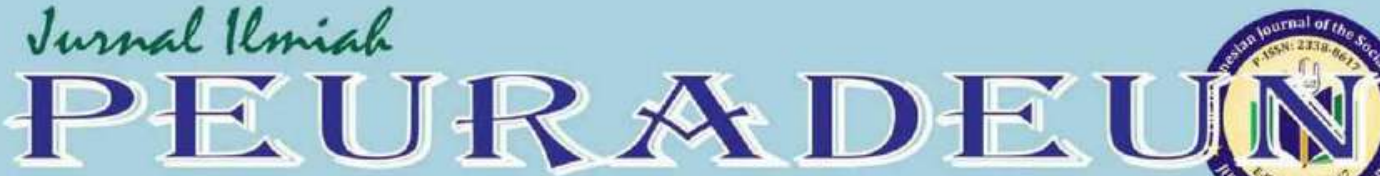

Vol. 6, No. 1, January 2018

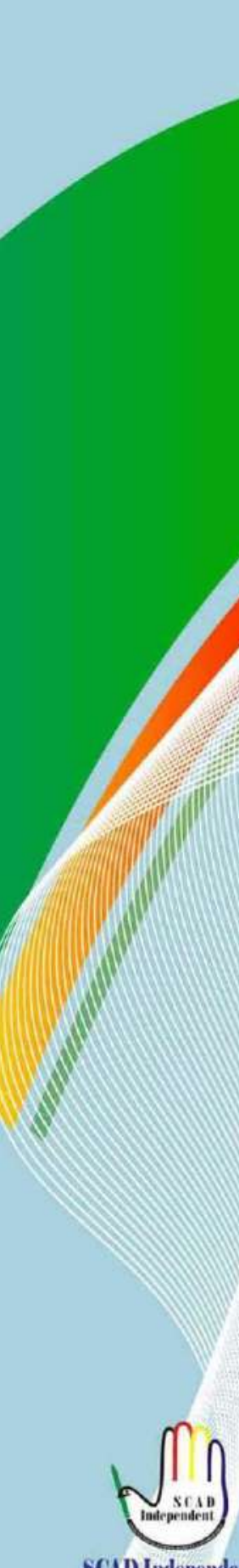

SCAI) Independent Accreditatioa by HO since 2014 $\bigodot$ Copernicus Publications

\section{III}

The Indonesian Journal of the Social Sciences www.journal.scadindependent.org Dot Prefix Number: 10.26811

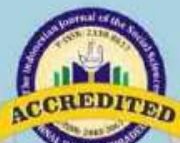

ACCREDITED - B" by the Ministry of Risteklikti from Oetaber 30, 2017 until Oetober 30, 2022

\section{Clarivate Analytics}

Emerging Sources Citation Index Web of Science ${ }^{\mathrm{TM}}$

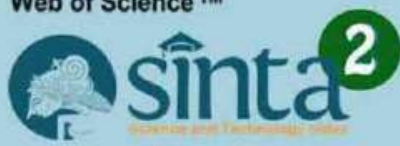
INDEX $\circledast$ COPERNICUS 


\title{
ENVIRONMENTAL EDUCATION AND ECOTOURISM FOR SUSTAINABLE LIFE: LITERATURE STUDY
}

\author{
Dian Aswita \\ Faculty of Teacher Training and Education, Serambi Mekkah University, Aceh, Indonesia \\ and Postgraduate at Yogyakarta State University, Yogyakarta, Indonesia \\ Contibutor Email:aswita_dian@yahoo.com
}

Received: Jul 07, 2017

Accepted: Aug 27, 2017

Published: Jan 28, 2018

Article Url: http://journal.scadindependent.org/index.php/jipeuradeun/article/view/157

\begin{abstract}
This study discusses the results of the research related to ecotourism and environmental education in relation to sustainable life. This study is a literature study. Data were obtained from articles and books related to environmental education and ecotourism and were analyzed using qualitative descriptive analysis techniques. The results show that the purpose of environmental education is to teach and educate the public about natural environment and ecosystems in order to sustain life. Ecotourism and environmental education are inseparable and must be mutually supportive. Ecotourism development requires environmental education as the base, as much as a tourist area can be used as a source for learning about environment for everyone. Environmental education is intended to improve knowledge about environment which encourages attitude and pro-environmental behaviors, as well as having a positive attitude towards ecotourism and environmental conservation. There is a strong positive correlation between environmental knowledge and people's attitudes towards ecotourism. The study shows that there was a positive correlation of 0.70 , which confirms that environmental knowledge (EK) positively influences youth's attitude towards ecotourism (EA).
\end{abstract}

Keywords: Ecotourism, Environmental Education, Sustainable Life 


\section{A. Introduction}

Ecotourism is an activity that utilizes natural resources in the form of tourist attraction that aims to educate, conserve and contribute to the economy of the people and the state. Jaini, Anuar and Daim (2012: 175), mention that ecotourism can be defined as a concept that focuses on conservation, preservation, social, and economic benefits. The goal of ecotourism is to provide a sustainable tourism where tourists enjoy their visit without causing a negative impact on the site, while communities are getting benefit from the tourism industry. Similar to what was stated by $\mathrm{Su}$, Wall and Ma (2014: 1190), the development of ecotourism is closely related to the sustainability of a protected natural area. When it is facilitated by appropriate management, ecotourism can contribute to conservation, development, and welfare of local communities. Thus, ecotourism can be interpreted also as tourist activities that consider ecological values in order to improve the welfare of the people around tourist sites.

The most important criteria of ecotourism is the existence of conservation activities among the tourist activities, the involvement of communities, and benefits and sustainability. It is also described in the book of UNEP (2013: 276), that ecotourism is defined as forms of tourism which have the following characteristics:

1. All nature-based forms of tourism in which the main motivation of the tourists is the observation and appreciation of nature as well as the traditional cultures prevailing in natural areas.

2. It contains educational and interpretation features.

3. It is generally, but not exclusively, organised by specialised tour operators for small groups. Service provider partners at the destinations tend to be small, locally owned businesses.

4. It minimises negative impacts upon the natural and socio-cultural environment.

5. It supports the maintenance of natural areas which are used as ecotourism attractions by: 
a. Generating economic benefits for host communities, organisations and authorities managing natural areas with conservation purposes;

b. Providing alternative employment and income opportunities for local communities; and

c. Increasing awareness towards the conservation of natural and cultural assets, both among locals and tourists.

Ecotourism component consists of: (1) contribute to the conservation of biodiversity; (2) sustain the welfare of local communities; (3) include interpretation / learning experience; (4) involve responsible action from both the tourists and the tourism industry; (5) delivered, especially for small groups with small businesses; (6) require the lowest possible consumption of non-renewable resources; and (7) emphasize local participation, ownership and business opportunities, particularly for rural communities (Wood, 2002: 10). Bhuiyan, Chamhuri, and Rabiul (2010: 43), say that "the term ecotourism can be well explained by the following five criteria, namely nature conservation, low impact environment, sustainability, community involvement, and environmental education. Environmental education must be fulfilled for the implementation of ecotourism and a step in the process of understanding the ecosystem. The purpose of environmental education is to teach and educate the public about the natural environment and ecosystems in order to live sustainability". Environmental education is a continuous and multi-sector process, as well as a tool to stimulate reflection, discussion and decision on issues and problem environmental (IIEP, 2006: 8).

There is one point of view which states that, ecotourism is to share, recognize and protect the natural and cultural heritage from destruction under the direction of view and the ecological theory. Ecotourism is a specific tour activity in some form of educational ecological and popularizing of Ecology. This definition reflects the fact that ecotourism has the connotation of certain education. Namely, ecotourism has the objective to protect the ecological environment and educate ecological tourist and other tourism stakeholders (Wang, 2010: 261). 
The purpose of this article is to determine: (1) potency of environmental education in the development of ecotourism; (2) relationship between environmental education and sustainable ecotourism; (3) learning models of environmental education in ecotourism; and (4) impact of environmental education on the behavior of individual and a conservation ethic.

\section{B. Research Methods}

This is a literature study, which review the results of research related to environmental education and ecotourism. The sources of this literature review were articles (journals and proceedings) and books related to environmental education and ecotourism. There are four variables that were examined: (1) potency of environmental education in the development of ecotourism; (2) relationship between environmental education and sustainable ecotourism; (3) learning model of environmental education in ecotourism; and (4) impact of environmental education on the behavior of individuals and a conservation ethic. The data were analyzed using qualitative descriptive analysis techniques.

\section{Results and Discussion}

1. Potency of Environmental Education in the Development of Ecotourism

An understanding of environment can be obtained from environmental education, which later becomes a determining factor in people's? interaction with their environment. According to Bhuiyan, Chamhuri, and Rabiul (2010: 43), environmental education is included as one of the five criteria for ecotourism. Environmental education helps us to understand the natural ecosystem, conservation, and the role of communities in preserving the environment. The purpose of environmental education is to teach and educate the community about environmental functions. It also gives emphasis to the management of humans' behavior toward ecosystems and conservation so that they can be sustainable. Environmental education is beneficial for ensureing the development of ecotourism and to gather knowledge about environment. 
Furthermore, Bhuiyan, Chamhuri, and Rabiul (2010: 43), explain that ecotourism and environmental education is closely related and dependent on each other. The success of ecotourism cannot be achieved without appropriate environmental education. Some of the prerequisites for the development of ecotourism and environmental education are as follows:

a. A clear awareness of economic, social, political and ecological tourism.

b. Knowledge, values, and attitudes to protect and improve environment.

c. Meaningful behavior towards environment.

d. To assign response of ecotourism activities for environmentally sustainable development.

Ecotourism cannot be separated from the local people, which they can be organizers of tourism activities, such as a tour guide. The involvement of local people would be able to provide alternative employment and income opportunities for local communities. Thus, the tour guide should also have a proper understanding of the environment that used as a tourist attraction. Skanavis and Christos (2009: 49), in their research in Greece, it is known that is necessary to integrate the environment in the understanding of the ecotourism guide training. Focusing on the development of capabilities that can allow ecotourism guides to communicate and understand the importance of the environment, to promote practices that have minimal impact, to ensure the sustainability of the natural environment and culture, and to motivate tourists to evaluate the quality of life in relation to ecological concerns or the broader culture. The underlying reasons for this goal is by giving proper and effective understanding from the site ecotourism as well as monitoring and modeling responsible behavior towards the environment, the result will promote the positive impact of tourism and reduce negative impacts, local communities will be encouraged to participate in environmental management oriented ecotourism.

Thus, it can be seen that ecotourism and environmental education is integrated and mutually supporting so can contribute to the development of each other. We need environmental education to develop 
ecotourism as the base, and a tourist area can be used as a source of learning environment for everyone.

\section{Relationship Between Environmental Education and Sustainable Ecotourism}

Along the last decade, the World Commission on Environment and Development (WCED) has organized the framework of the problems facing the global community. Sustainable development has become concerned to everyone. Almost all political leaders, policy makers and program administrators can talk about sustainable development and that combine many ideas into their future policy. Sustainable development initially focused on economic growth and has now begun to consider environmental, social, and health problems on an individual basis. It is expected still be enjoyed by the future generations. The concept of sustainable development must be holistically and critically understood and compared with alternative environment approaches. One of the industry began calling for sustainable development was also felt in the tourism industry. Therefore, education should play an important role, especially environmental education (Skanavis and Christos, 2009: 52).

In order to increase mass awareness of environmental protection and the general quality, focus and emphasize ecotourism education and ensure the needs of the development of sustainable ecotourism, Wang (2010: 261) puts advanced ecotourism education and enriched the connotation through comparison of traditional tourism or ecotourism in the subject of education, educational methods, educational content and the results (Table 1). This means that, advanced ecotourism education referring to the promotion and popularization of knowledge ecotourism socialized and popular from different perspectives with different shapes to grow the concept of sustainable development among tourism stakeholders, improving knowledge and awareness of basic ecotourism them and improve their capacities and skills of environmental protection ecological 
Tables 1. Comparison Between Advanced Ecotourism Education, Traditional Tourism Education and Basic Ecotourism Education

\begin{tabular}{|c|c|c|c|}
\hline Feature & $\begin{array}{l}\text { Traditional } \\
\text { Tourism }\end{array}$ & Ecotourism & $\begin{array}{c}\text { Advanced Ecotourism } \\
\text { Education }\end{array}$ \\
\hline Purpose & $\begin{array}{l}\text { The economic } \\
\text { benefits }\end{array}$ & $\begin{array}{l}\text { Economic benefits } \\
\text { and environmental } \\
\text { benefits }\end{array}$ & $\begin{array}{l}\text { The economic benefits, } \\
\text { environmental benefits } \\
\text { and social benefits }\end{array}$ \\
\hline $\begin{array}{l}\text { Subject of } \\
\text { Education }\end{array}$ & $\begin{array}{l}\text { Tourism } \\
\text { developers, } \\
\text { operators and } \\
\text { managers, and } \\
\text { service } \\
\text { personnel of } \\
\text { tourism }\end{array}$ & $\begin{array}{l}\text { Tourism developers, } \\
\text { operators and } \\
\text { managers, and } \\
\text { tourists }\end{array}$ & $\begin{array}{l}\text { Tourism developers, } \\
\text { operators and } \\
\text { managers, tourists, } \\
\text { residents in the area of } \\
\text { tourism and tourism } \\
\text { service personnel }\end{array}$ \\
\hline $\begin{array}{l}\text { Educational } \\
\text { Method }\end{array}$ & $\begin{array}{l}\text { Formal } \\
\text { education and } \\
\text { training }\end{array}$ & $\begin{array}{l}\text { Particular emphasis } \\
\text { on formal education } \\
\text { and training and } \\
\text { assistance of } \\
\text { propaganda means }\end{array}$ & $\begin{array}{l}\text { The same significance } \\
\text { of formal education, } \\
\text { training and } \\
\text { propaganda }\end{array}$ \\
\hline $\begin{array}{l}\text { Educational } \\
\text { Content }\end{array}$ & $\begin{array}{l}\text { Improving the } \\
\text { competence of } \\
\text { management } \\
\text { and service } \\
\text { skills of tourism } \\
\text { practitioners }\end{array}$ & $\begin{array}{l}\text { Training of } \\
\text { ecological } \\
\text { environmental } \\
\text { awareness of tourism } \\
\text { practitioners }\end{array}$ & $\begin{array}{l}\text { Training concept of } \\
\text { sustainable } \\
\text { development of } \\
\text { tourism groups that are } \\
\text { relevant, and ecological } \\
\text { improvement, } \\
\text { environmental } \\
\text { protection awareness } \\
\text { and competence }\end{array}$ \\
\hline Results & $\begin{array}{l}\text { Short-term and } \\
\text { unstable } \\
\text { development }\end{array}$ & $\begin{array}{l}\text { Relatively stable } \\
\text { development }\end{array}$ & $\begin{array}{l}\text { Long-term and stable } \\
\text { sustainable } \\
\text { development }\end{array}$ \\
\hline
\end{tabular}

In addition, Gilbert (2003: 76-79), explains that, a sustainable approach to tourism development is one of respect for the integrity of the environment in all aspects, to promote human welfare and environmental quality, and uphold the values of human rights, justice, and conservation. Ecotourism can be an important model of this approach and has a lot of thing to offer in the education environment so it can be sustainable. His research describes the evolution that moves from an emphasis on behavioral change, understanding, knowledge, awareness, and skills, to the broader concept with a primary focus on equity, quality of life, human 
rights, and environmental quality. Reached the point that sustainable development research to emphasize the element of economic, social, and political as well as the environment, so education for sustainability need to do the same.

\section{Learning Model of Environmental Education in Ecotourism}

The learning experience can also be done simultaneously with ecotourism activities. The common ecotourism activities is learning about the environmental and socio-cultural community. The process of learning about environmental education not only in the formal environment, but also on non-formal and informal environments. Walter (2009: 392), in his research mentioned that there are some varieties of adult learning that occurs in many forms of ecotourism. A comprehensive review of research literature in the field of ecotourism, environmental education, and adult education used to identify: (a) the destination, (b) learning activities, and (c) the results of adult learning for each of the three types of ecotourism. Results adult learning models are presented in Table 2 below:

Tables 2. Adult Learning Model With Ecotourism

\begin{tabular}{|c|c|c|c|c|}
\hline $\begin{array}{c}\text { Type of } \\
\text { Ecotouris } \\
\text { m }\end{array}$ & Aims & $\begin{array}{l}\text { Learning } \\
\text { Activities }\end{array}$ & Outcomes & $\begin{array}{c}\text { Philosoph } \\
\text { y }\end{array}$ \\
\hline Nature & $\begin{array}{l}\text { Changes in } \\
\text { behavior: } \\
\text { promote } \\
\text { nature and } \\
\text { wildlife } \\
\text { conservation }\end{array}$ & $\begin{array}{l}\text { - } \text { Guided } \\
\text { walks } \\
\text { - Nature } \\
\text { centers } \\
\text { - Wildlife } \\
\text { watching } \\
\text { - Interpretiv } \\
\text { e Program }\end{array}$ & $\begin{array}{l}\text { - Increased } \\
\text { knowledge } \\
\text { - Appreciation } \\
\text { of aesthetics } \\
\text { - Environment } \\
\text { al awareness } \\
\text { - Actions for } \\
\text { conservation }\end{array}$ & $\begin{array}{l}\text { Liberal } \\
\text { Behavioris } \\
t\end{array}$ \\
\hline Adventure & $\begin{array}{l}\text { Psychologic } \\
\text { al changes: } \\
\text { self- } \\
\text { confidence, } \\
\text { self- } \\
\text { fulfillment } \\
\text { - Knowledge } \\
\text { of the } \\
\text { environment }\end{array}$ & $\begin{array}{l}\text { - Guided } \\
\text { camping, } \\
\text { hiking, } \\
\text { rafting, } \\
\text { canoeing, } \\
\text { kayaking, } \\
\text { mountain } \\
\text { climbing }\end{array}$ & $\begin{array}{l}\text { - New skills } \\
\text { and } \\
\text { knowledge } \\
\text { - Psychologic } \\
\text { al changes } \\
\text { - environmen } \\
\text { tal action }\end{array}$ & $\begin{array}{l}\text { Progressive } \\
\text { Humanist }\end{array}$ \\
\hline
\end{tabular}


Dian Aswita

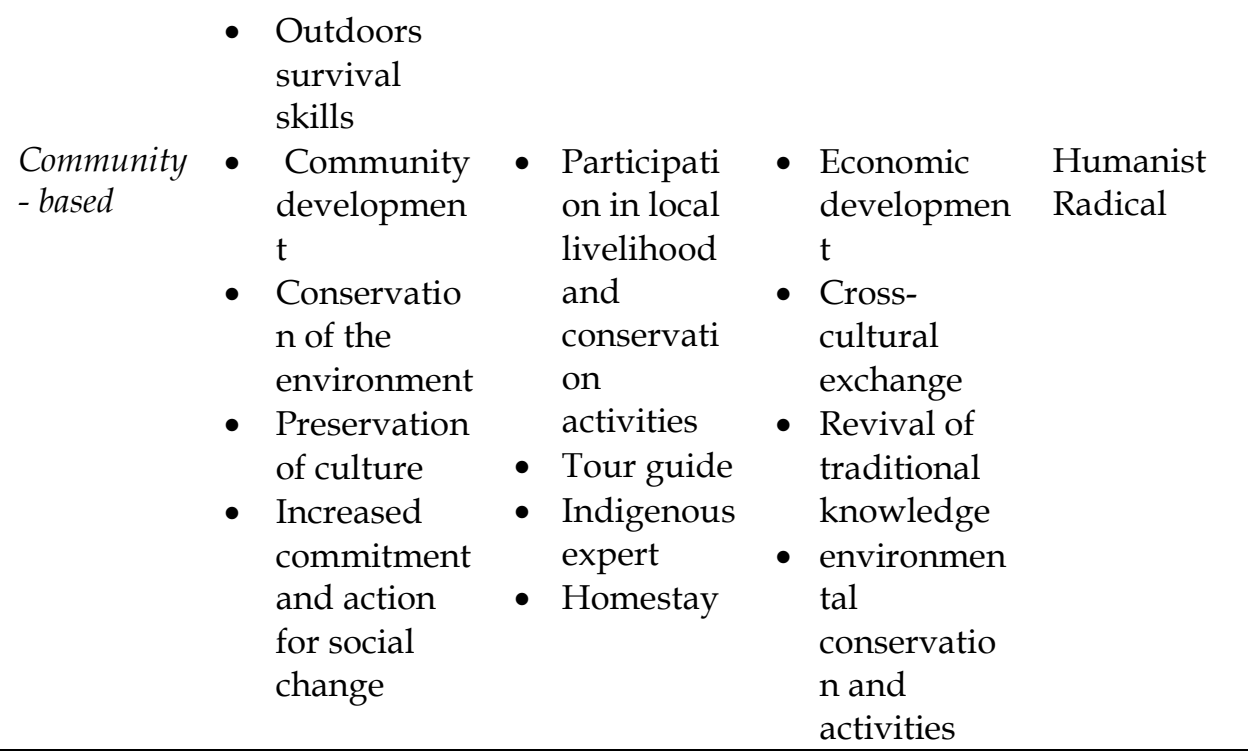

Based on the results of Niesenbaumand and Barbara research (2001: 13-15), shows the development of eco-education program at the national level colleges that are trying to harness the power of ecology and ecotourism education by forming partnerships with local communities. This educational program has key features:

a. international experience, which combines international experience in eco-education program is an effective way to teach biocultural conservation;

b. interdisciplinary collaboration, which is intended to overcome the shortcomings and expertise in interpreting what they see, to achieve a better understanding of the complex problems;

c. social interaction, which is a key element of the program ecoeducation, which we can learn about the environment and culture from the local experts who are local people, this relationship can also contribute to the economy of the community, as well as allowing it to move sustain conservation;

d. the experience and service learning, where students can develop and conduct independent research and participate in projects oriented services, so students have to interact with the 
environment and people, as well as the opportunities offered to learn through investigation of individuals, regarded as one the most effective approach to education;

e. follow-up component of the campus, where the purpose from this activity is a follow-up to try the students to be able to apply the lessons they learned in the outside environment to solve the problems of daily life;

f. the consistency with the aim of the institution, where most higher education institutions express the commitment of globalization or internationalization, interdisciplinary learning, environmental and social awareness. The hope is not only to be formed environmental ethic and strong conservation to students but it will also contribute significantly to community-based conservation efforts.

\section{Impact of Environmental Education on the Behavior of Individuals and a Conservation Ethic}

Knowledge about environment strongly influence attitudes towards ecotourism. Community involvement in ecotourism can be stimulated through: appropriate management strategies to increase knowledge of their environment; promote ecotourism ecotourism positive attitudes and environmental planning that promote affinity of community for local attractions. Environmental knowledge has positive effect on attitudes towards the environment. A positive attitude society towards ecotourism, especially with regard to the characteristics and principles of ecotourism management, may furthermore encourage their active involvement in local tourism. Build community capacity in the use of sustainable natural resources is the key for promoting positive attitudes towards ecotourism and environmental conservation. Based on the research result shows that there is a strong positive correlation between the environmental knowledge and their attitudes towards ecotourism. A positive correlation of 0.70, which confirms that the hypothesis: $\mathrm{H} 0$. Environmental Knowledge (EK) positively influence the attitudes of youth towards Ecotourism (EA) (Wanga, et. al., 2013: 110). 
According Untaru, Ispas, and Candrea (2015: 109), in the tourism industry, environmental education has an important place because it is not only a significant impact on raising the awareness of individuals, but also on their attitudes and behavior towards environmental issues. The main causes of environmental problems that exist in the world is the lack of information on the ecosystem, and therefore environmental education becomes important to understand. Developing the ability to identify environmental problems, to make decisions, to implement the solution in preventing and resolving problems identified can be achieved only through education. Research shows that practicing various forms of tourism determines the positive behavioral development, creative and innovative, which contributes to the development of society, in general.

Ecotourism is based on three main concepts: the conservation and protection of the environment, support local culture and economy, and environmental education for local people and tourists. Sander (2012: 397401) in his research on Rara Avis, found that education have an effect on the knowledge acquired and improved conservation ethic, and that ecotourism can be used as a vehicle for formal and informal environmental education. Outstanding combination occurs when students, tourists, tour guides and researchers often create a learning atmosphere in the travel environment. The tour guides can learn from students and tourists as well as researchers to improve their knowledge. The guide, then can share the knowledge they gained from the constant flow to other visitors, creating ongoing cycle learning of a knowledge. For tourists who have gained an understanding of the environment, there is a commitment in which they have the will to do conservation by minimizing the environmental impact of all them activities damaging during the tour and intends to do environmental preservation. This study shows that knowledge can be gained and a conservation ethic can be improved when someone making tours.

\section{Conclusion}

Based on the research above, the following conclusions can be taken, that is: 
1. Tourism and the environment have an interdependent relationship, where tourism is almost always depends on the quality of the environment. And environmental quality or specific characteristics of the environment, commonly became a tourist attraction.

2. Ecotourism should be developed in harmony with the environment, which should not only meet the needs of tourism development, but should also bring positive effects for the environment. We need to establish the concept of ecological tourism on the whole community and recalls the awareness of sustainable development and the concept of "respecting the ecotourism resources and environment for the growth and development of future generations".

3. In the field of tourism, education is very important, because it can help to inform people and raise their awareness about environmental issues, thus giving a significant influence on the attitudes and behavior of environmentally friendly.

4. Ecotourism and environmental education is a unity of mutual support, where ecotourism development requires environmental education as the base, and the tourist area can be used as a source of learning environment for everyone.

5. Sustainable approach to tourism development is one of respect for the integrity of the environment in all aspects, to promote human welfare and environmental quality, and uphold the values of human rights, justice, and conservation. Ecotourism can be an important model of this approach and has a lot of thing to offer in the education environment so it can be sustainable.

\section{References}

Aswita, D., Sarong, M. A., \& Sugianto, S. (2015). Early Study of Aquatic Biodiversity in Teupin Layeu Iboih Sabang for Marine Ecotourism. Jurnal Ilmiah Peuradeun, 3(3), 381-390.

Bhuiyan, Md. A. H., Chamhuri, S., and Rabiul, I. 2010. Ecotourism and Environmental Education: An Opportunity for Bangladesh. Proceeding of International Conference on Environmental Aspects of Bangladesh (ICEAB10), Japan, Sept, 2010. 
Gilbert, R. 2003. Invited Essay -Ecotourism and Education for Sustainability: A Critical Approach. International Review for Environmental Strategies, Vol. 4, No. 1, pp. 75 - 83, 2003.

Herlina, H., \& Hamzah, A. (2015). Domestic Tourists' Response to Tourist Attractions in Sabang and Banda Aceh, Indonesia. Jurnal Ilmiah Peuradeun, 3(3), 371-380.

International Institute for Educational Planning (IIEP). 2006. Environmental Education: Guidebook for Planning Educayion in Emergencies and Reconstruction. Paris: IIEP's printshop, ISBN: 92-803-1288-X, UNESCO 2006.

Jaini, N., Anuar, A. N. A., and Daim, M. S. 2012. The Practice of Sustainable Tourism in Ecotourism Sites among Ecotourism Providers. Asian Social Science Vol. 8, No. 4, April, 2012.

La Torre, C. G., \& Montalto, K. F. (2016). Transmigration, Multiculturalism and Its Relationship to Cultural Diversity in Europe. Jurnal Ilmiah Peuradeun, 4(1), 39-52.

Meraj, M. A. (2016). Islamic Approach to The Environment and The Role's in The Environment Protected. Jurnal Ilmiah Peuradeun, 4(1), 1-14.

Niesenbaum, R. A., and Barbara, G. 2001. Community-Based EcoEducation: Sound Ecology and Effective Education. The Journal of Environmental Education, Vol 3, No. 1, pp. 12-16, 2001.

Pratama, A. H., Gunawan, B., \& Cahya, B. (2016). Social Impact of Mangrove Land Conversion in Dimensions as Rural Sustainability. Jurnal Ilmiah Peuradeun, 4(3), 357-368.

Sander, B. 2012. The Importance of Education in Ecotourism Ventures: Lessons From Rara Avis Ecolodge, Costa Rica. Int. J. Sustainable Society, Vol. 4, No. 4, 2012.

Skanavis, C., and Christos, G. 2009. Improving Quality of Ecotourism Through Advancing Education and Training for Eco-tourism Guides: The Role of Training in Environmental Interpretation. Tourismos: An International Multidisciplinary Journal Of Tourism, Vol. 5, No. 2, Autumn 2010, pp. 49-68, UDC: 338.48+640(050), 2009.

$\mathrm{Su}$, M. M., Wall, G., and Ma, Z. 2014. Assessing Ecotourism from a Multistakeholder Perspective: Xingkai Lake National Nature Reserve, China. Environmental Management, 54:1190-1207, DOI 10.1007/s00267-014-0360-5, 2014. 
Tabrani. ZA \& Masbur, M. (2016). Islamic Perspectives on the Existence of Soul and Its Influence in Human Learning (A Philosophical Analysis of the Classical and Modern Learning Theories). Jurnal Edukasi: Jurnal Bimbingan Konseling, 1(2), 99-112.

United Nations Environment Programme (UNEP). 2013. Green Economy and Trade - Trends, Challenges and Opportunities. Available at: http://www.unep.org/greeneconomy/ GreenEconomyandTrade, 2013.

Untaru, E. N., Ispas, A., and Candrea, A. N. 2015. An Overview of Environmental Education Initiatives in the International and Romanian Tourism. Bulletin of the Transilvania University of Braşov. Series V: Economic Sciences, Vol. 8 (57) No. 1, 2015.

Vitoria, L., \& Monawati, M. (2016). Improving Students' Problem Solving Skill in Mathematics Through Writing. Jurnal Ilmiah Peuradeun, 4(2), 231-238.

Walidin, W., Idris, S \& Tabrani. ZA. (2015). Metodologi Penelitian Kualitatif dan Grounded Theory. Banda Aceh: FTK Ar-Raniry Press

Walter, P. 2009. Adult Learning in Ecotourism: The Current State of Research. Proceedings of the 50th Annual - Adult Education Research Conference. National - Louis University Chicago, Illinois. May 28-30, 2009.

Wang, X. 2010. Critical Aspects of Sustainable Development in Tourism: Advanced Ecotourism Education. Journal of Sustainable Development Vol. 3, No. 2; June 2010.

Wanga, J. O., Patrick, O. H., Pius, O. O., and Fredrick, Z. A.O. 2013. The Nexus between Environmental Knowledge and Ecotourism Attitude Among the Local Youths in Co-Educational Secondary Schools in Bondo Sub-County, Siaya County, Kenya. International Journal of Business and Social Research (IJBSR), Vol. 3, No.7, July, 2013.

Wood, M. E. 2002. Ecotourism: Principles, Practices $\mathcal{E}$ Policies for Sustainability. France, United Nations Publication, ISBN: 92-8072064-3, 2002. 